\title{
CIPP evaluation model for the coaching program of running athletes
}

\author{
Eki Aldapit ${ }^{1 *}$, Suharjana Suharjana ${ }^{2}$ \\ ${ }^{1}$ Universitas Muhammadiyah Kotabumi. Jalan Hasan Kepala Ratu No.1052, Sindang Sari, Kotabumi, Kabupaten \\ Lampung Utara, Lampung 34517, Indonesia \\ ${ }^{2}$ Universitas Negeri Yogyakarta. Jalan Colombo No. 1 Yogyakarta, 55281, Indonesia \\ * Corresponding Author. E-mail: al_dapit@yahoo.co.id
}

Received: $6^{\text {th }}$ September 2018; Revised: $2^{\text {nd }}$ September 2019; Accepted: $4^{\text {th }}$ September 2018

\begin{abstract}
This study aimed to evaluate the training programs of sprinting, middle distance running, and long distance running athletes. This type of research is the study evaluation using CIPP models. The approach used in this study is a qualitative approach with qualitative data analysis model of Miles $\&$ Huberman. The results of the evaluation include: (1) context evaluation shows that there are lack of budget, facilities, government's support, sponsorship, health experts, test instrumens and test spaces, (2) evaluation of the inputt indicates there is a lack of facilities and infrastructure as the main support of the running track, (3) evaluation of the process demonstrates the ability of trainers to implement the training process is very helpful to the achievement of a good coaching program and achievements of athletes. The recruitment of athletes should be open to all people, so there should not be the impression of nepotism and collusion, (4) evaluation of the product shows the achievements have been at national and international level. Achievement would be better and more sustainable if supported by a context and a perfect addition of the input to the process which has been good.
\end{abstract}

Keywords: program evaluation, development, running athletes, athletic club

How to Cite: Aldapit, E., \& Suharjana, S. (2019). CIPP evaluation model for the coaching program of running athletes. Psychology, Evaluation, and Technology in Educational Research, 1(2), 104-116. doi:http://dx.doi.org/10.33292/petier.v1i2.10

\section{INTRODUCTION}

Evaluation is an important part in any program or any activity that has been planned and has been implemented through a sequence of process for achieving the already-defined objectives. The results of an evaluation will be influenced by the plan and the process within the program or the activity. With regards to evaluation, the results of the observation toward the athletic clubs in the Province of Yogyakarta Special Region show that the coaching process within the athletic clubs in the Province has not been evaluated yet. Therefore, the coaching activities in the athletic clubs should be thoroughly evaluated and the evaluation that will be conducted should be based on the events that have been held. Considering the results of the observation, it is deemed necessary that an evaluation should be conducted to the coaching process of the athletic clubs in the Province of Yogyakarta Special Region.

Then, the objective of conducting a program evaluation is to gather recommendations. The recommendations are attained from the results of the analysis review toward the data that have been gathered from the field (Arikunto \& Jabar, 2009, p. 128). Specific to the context of the study, the evaluation toward the coaching programs will assist the identification of the problems that have been found. In order to identify the description on the evaluation results and the problems that have taken place in the sport-coaching activities, the context, the input and the product of the coaching process that has been implemented should be identified. Therefore, within the conduct of the study the model that will be adopted is the CIPP (Context, Input, Process and Product) Evaluation Model. 


\section{Psychology, Evaluation, and Technology in Educational Research, 1 (2), 2019, 105}

Eki Aldapit, Suharjana Suharjana

The more effective the performance of a system is, the better the quality will be. On the contrary, the less effective the performance of a system is, the poorer the sport development will be (Hidayatullah, 2016). In other words, the sport system that has performed effectively will improve the quality of the sport development. In relation to the statement, the results of the observation in the field show that the coaching system has not been implemented well. This description is apparent from the difficulties that the coach has experienced in coordinating one athlete to another. Furthermore, the results of the observation from the regional game show that there has been discrepancy on the performance of the athletes from one regency to another. In the same time, the results of the observation during the regional game also show that there have been several athletes who are unable to complete their game.

Law Number 3 of 2015 on National Sport System Article 4 Basics, Functions and Objectives states that the objective of the National Sport System is to gain achievement, human resources quality, moral value and nobility internalization, sportsmanship, discipline, national unity and integrity development, national defence strengthening, and national dignity elevation (Republik Indonesia, 2005). In order to support the objective of the National Sport System, the Government of the Republic of Indonesia nowadays has held many sport events under the expectation that the well-qualified athlete candidates might be found. However, the efforts that support the objective of the National Sport System has not been able to bring great success for Indonesia in the international level. Therefore, in order to achieve the objective of the National Sport System there should be coordination between the athletic clubs and the government. With regards to the statement, the results of the field observation during one month show that there has not been any coordination between the parties of interest, namely the athletic clubs and the government, toward the regional and the national achievement. As a result, the coordination between the parties of interest with regards to the athletic coaching activities in the Province of Yogyakarta Special Region should be evaluated.

In brief, the evaluation toward the athletic clubs should be conducted in order to identify how far the progress of the training programs for the national events and the coaching process that has been implemented is. In addition, the evaluation should be conducted in order to uncover the aspects that have been related to the training programs. In order that the evaluation is able to attain more comprehensive results, the model that will be adopted in conducting the evaluation is the CIPP model.

Under the same tone, the study is conducted in order to identify and to uncover the aspects that have been related the evaluation toward the athletic coaching activities in the Province of Yogyakarta Special Region. The evaluation itself is conducted in order to identify the results of the coaching activities that have been performed in the athletic clubs that have been based in the Province. Then, the evaluation that will be conducted in the study consists of the context, the input, the process and the product evaluation toward the coaching programs of each athletic club. Thus, in general the objective of the study is to evaluate the coaching programs of the running athletes in the Province.

\section{METHOD}

The study was an evaluation research. Within the evaluation research, the model that had been adopted in evaluating the coaching programs for the running athletics in the athletic clubs within the Province of Yogyakarta Special Region was the CIPP Model. CIPP stands for Context, Input, Process and Product (Astuti, Haryanto, \& Prihatni, 2018; Bukit, Bastari, \& Putra, 2019; Hanifah \& Irambona, 2019; Mulyatiningsih, 2011, p. 124; Nuruhidin, Putra, Pamungkas, Ardiyanto, \& Saputro, 2018; Stufflebeam, 2003; Tseng, Diez, Lou, Tsai, \& Tsai, 2010). Within the conduct of the study, the CIPP Evaluation Model was performed comprehensively in order to understand the activities within the coaching programs, starting from the program design until the program completion (Mawardi, 2019; Rohyani, Herpratiwi, \& Djasmi, 2014).

The approach that had been adopted in the study was the qualitative approach (Puspitasari, In'am, \& Syaifuddin, 2018). In the conduct of a qualitative study, the researcher makes use of consistent literatures based on the assumptions given by the participants and does not provide any space for the personal perspective of the researchers. In general, the conduct of a qualitative study is conducted under the consideration that the study should be explorative. The understanding that has been established within the a qualitative study should be based on the opinion that the participants have heard (Cresswell, 2016). This approach is intended to describe the data holistically. Furthermore, 


\section{Psychology, Evaluation, and Technology in Educational Research, 1 (2), 2019, 106}

Eki Aldapit, Suharjana Suharjana

the qualitative study is conducted by observing the participants in their living environment, building interactions with them, trying to understand the culture of the participants and establishing understanding toward the environment of the participants (Sudjana, 2006, pp. 212-213). The interview in the qualitative study thus should be conducted without any pressure and under natural setting. The answers to the questions should be given based on the opinion of the subjects without any pressure. With regards to evaluation, the evaluation by means of qualitative approach refers to the evaluation procedures that result in the descriptive data in the form of oral or written narratives from the facts that have been inquired or that have been observed. In other words, qualitative study might be considered as the research procedures that result in the descriptive data in the form of oral and written narratives and also people behaviours.

The study itself was conducted in the athletic clubs in the Province of Yogyakarta Special Region; specifically, the study was conducted in the athletic clubs that had been based in the Regency of Bantul, the Regency of Gunungkidul, the Regency of Sleman and the City of Yogyakarta. These areas had been selected because the number of the running athletes in these areas had been high. Then, the athletic clubs that had been sampled within the conduct of the study were the Sportif Athletic Club from the Regency of Gunungkidul, the Sparta Athletic Club and the Bantul Athletic Club from the Regency of Bantul, the BNHK Camp Athletic Clubn from the City of Yogyakarta and the Sembada Athletic Club from the Regency of Sleman.

Both the primary and the secondary data source that had been benefitted within the conduct of the study were attained from the subjects in relation to the athletic clubs that had been evaluated. In addition, the evaluation itself was also based on paper namely: (a) the documents of the athletic clubs under evaluation; (b) the documents of the athletes; (c) the documents of the coaches; (d) the magazines; (e) the books; (f) the journals; (g) the coaching programs of the Regional Branch of the Indonesian Athletics Federation; and h) the reports submitted by the Board of the Regional Branch of the Indonesian Athletics Federation. In the same time, the evaluation was based on the place namely: (a) training ground; (b) training facilities; and (c) exercise activities. Last but not the least, the evaluation is based on the person namely five coaches from all of the athletic clubs that had been sampled in the study.

The evaluation toward the coaching programs of the running athletes was intended to review and assess the information-processing activities in order to gather the information on these coaching programs. The information that had been reviewed was the plans that involved multiple units of running athlete coaching activities. The plans alone consisted of policies, a number of selected activities and number of prioritized activities.

The main instrument within the study was observation guideline, interview guideline and document study; these instruments had been designed based on the factors and the variables that should be studied. Then, the supporting instrument was designed through a semi-permanent manner; the implication was that the supporting instrument might be developed further in accordance to the given situations. The validity of the instrument was tested by performing the cross-check method and the expert judgment. The experts who had been involved in the expert judgment were the material expert, the exercise methodology expert and the academic sponsor. The validity that had been tested was the substance of the interview instrument so that the instrument might be implemented in gathering the necessary data for the conduct of the study.

Data gathering activities refer to the activities of recording events, matters, information and characteristics or structures of the element that will support the conduct of a study. In the context of the study, the data were gathered based on the CIPP Evaluation Model through interview, field observation and documentation.

Credibility test refers to the level of trustworthiness toward the data of the qualitative study results. On the other hand, confirmability within a qualitative study refers to the conduct of an audit toward the overall process of the study by the academic sponsor and starts from problem definition to field observation, data source selection, data analysis and eventually ends in conclusion. Therefore, the conduct of an audit toward the overall process within a qualitative study might be performed altogether in the same time. The audit should be conducted in order to avoid the perception that the results of a qualitative study have not gone through a proper process of investigation. Specific to the conduct of the credibility test, in order to gather the level of data validity trustworthiness a researcher should perform member check, triangulation and diligence (Arikunto, 2014). 


\section{Psychology, Evaluation, and Technology in Educational Research, 1 (2), 2019, 107}

Eki Aldapit, Suharjana Suharjana

Analysis refers to the process of data arrangement for the sake of interpretation. Data arrangement refers to the activities of classifying the data into certain patterns, themes or categories. Without data categorization or data classification, a chaos within the conduct of a study might take place. On the other hand, interpretation, or data interpretation, refers to the activities of elaborating the analysis results, explaining the pattern or the category and identifying the relationship among numerous concepts. According to Miles and Huberman (Darmayanti \& Wibowo, 2014; Emzir, 2012, pp. 129-134; Miles, Huberman, \& Saldaña, 2014), there are three kinds of activities in the data analysis of a qualitative study namely data reduction, data display; and verification.

\section{RESULTS AND DISCUSSIONS}

In this section, the results that have been gathered will be discussed and elaborated further based on the CIPP Evaluation Model. The discussions and also the elaborations might be consulted in the following sections.

\section{Context}

The Context Evaluation in the study consists of the following part: (a) background of the problems in the running athletes coaching programs; (b) plans on the running athletes coaching programs; (c) support from the government and the society; (d) support from the parents; and (e) support from the science. Each aspect will be explained further as follows.

\section{Background of the Problems in the Running Athletes Coaching Programs}

In the democracy system, the members of an organization hold the highest power within the organization. The reason is that the members of an organization delegate certain authority to the board of directors or the supreme leader. The main role of the board members is related to the service, the arrangement and the supervision toward the managerial activities. In the same time, the main role of the members is also related to the supervision on the organizational affairs so that the organizational objectives might be achieved well (Harsuki, 2012, p. 41). With regards to the explanation, the results of the analysis toward the five athletic clubs in based in the Province of Yogyakarta Special Region have been various from one to another. However, generally the results of the analysis show that the Bantul Athletic Club, the Sparta Athletic Club and the Sportif Athletic Club have been in the "Good" level. The reason is that these athletic clubs have been well-settled and have been supported by the solid organizational or caretaking structure.

The huge, stable and continuous financial support becomes the main prerequisite for the coaching programs of sports for achievement. The huge allocation in the coaching programs demands well-functioning financial plan and management (Lutan, 2013, pp. 34-35). With regards to the statement, cost is a component of multiple factors that should be properly dealt with in the management. From the data analysis of the five athletic clubs that had been based in the Province of Yogyakarta Special Region, it is found that the achievement of the athletic clubs in meeting the budget in order to maintain and meet the operational needs has been low. The reason is that the athletic clubs have still been relying on the coaches and the board members in meeting the operational needs, especially in terms of coaching process and nutritional needs for the athletes.

For example, one of the main obstacles in the developing athletics throughout Africa in general and throughout Tanzania in specific has been related to the equipment availability. The development of the basic facilities and equipment for the wide practical use has very valuable contribution for the athletic sports (Thumm, 2006, 2019). The similar economic situations between Africa and Indonesia have shown that the indication on the needs of the facilities is almost similar. In terms of facilities, Indonesia has been dealing with the similar problems that Africa has been suffering from but, despite the facilities-related problems, Africa has been able to generate international-level running athletes. According to (Lutan, 2013, p. 44), it is impossible to perform sport activities without the support from the training facilities. For the coaching activities of sports with achievement, the presence of the standardized facilities should be afforded because the presence of the standardized facilities is able to influence the mastery of both the techniques and the tactics. Therefore, the provision of the training facilities should meet the criteria of efficiency. In other words, the sufficient training facilities have very huge contribution to the success of the Athletic. Then, as having been implied previously, the data from the five athletic clubs that have been studied show that the achievement of the five athletic 


\section{Psychology, Evaluation, and Technology in Educational Research, 1 (2), 2019, 108}

Eki Aldapit, Suharjana Suharjana

clubs in meeting the needs of the facilities for the coaching activities has been low. In order to deal with this situation, the management of the five athletic clubs meet the needs of the facilities independently by relying on the personal fund. Consequently, the facilities such as running track in overall have not met the standards for the better coaching activities especially in relation to the preparation for both the national and the international events.

The mission of sport coaching activities is to improve the achievement of both the national-level athletes and the international-level athletes through the improvement on the coaching quality standards, coach development and also sports science and technology implementation. Achievement is the main objective of the sports coaching and development. In relation to the statement, the data from the five athletic clubs show that the achievement of the athletes since the foundation of the athletic clubs has been good. However, over the course of time the athletic clubs based in the Province of Yogyakarta Special Region have been low in terms of achievement during certain period of time.

Athlete coaching activities are part of national develolpment and therefore these activities should be given special attention. In relation to the statement, the five athletic clubs within the study have properly handled these problems. The problems behind the coaching activites might be properly solved although the athletic clubs should adjust themselves to the existing conditions.

In addition, the genetic condition of the athletes has been very influential; as a result, the potentials of the athletes in improving their capacity are very low and yet the program details should be appropriate. The training age (the number of annual training for sports) is more meaningful than the chronological age in categorizing the athletes (Brown \& Ferrigno, 2014, p. 4). The duration of the training period will influence the athletes' training age so that it is important for the sports coaching activities to pursue the grassroot coaching programs. The reason is that the grasroot coaching programs will automatically train the athletes for a long period of time and influence the final results. In this regard, the data show that in relation to attaining and coaching potential athletes four athletic clubs, namely the Bantul Athletic Club, the Sparta Athletic Club, the Sportif Athletic Club and the Sembada Athletic Club, have been in the "Good" capability. On the other hand, one athletic club, namely the BNHK Camp Athletic Club, has been in the "Poor" category. The achievement of the four clubs has been supported by the government through the conduct of certain events such as Students Sports Championship in the Provincial Level and the National Science and Sports Olympics in the level of Elementary School, Junior High School and Senior High School. These events have assisted the four athletic clubs to select and recruit the potential athletes.

Plans on the Running Athletes Coaching Program

The main benchmark for the successful coaching activities of the sports for achievement is the health of the sports organization and this is related to several indicators. The intended indicators are namely: (a) the minimum formal structure of the organization that has been established in accordance to the Articles of Association and the Bylaws; (b) the implementation of the managerial function in accordance to the main duty and the function of the organization; and (c) the amount of time devoted by the caretakers and also the competence, the commitment and the care of the caretakers (Lutan, 2013, p. 36). From the data that have been gathered in the study, in this regard three athletic clubs, namely the Bantul Athletic Club, the Sportif Athletic Club and also the Sparta Athletic Club, have good achievement whereas two athletic clubs, namely the BNHK Camp Athletic Club and the Sportif Athletic Club, have moderate achievement. The three athletic clubs have good planning for the coaching activities and have been supported by the well-functioning Articles of Association and the Bylaws. The planning of the three athletic clubs has followed the periodisation of the training programs with objectives toward certain events.

According to (Lutan, 2013, p. 46), the objective of the coaching activities is to improve the quality standards of competition, to pursue the national parameter and even to pursue the international parameter. The objective of the planning is to attain the maximum results in the form of winner or increasing time record. All of the achievements in this regard have been good because the five athletic clubs within the study have objective plan in the national level.

\section{Support from the Government and the Society}

The support from the regional government, the provincial government and even from the central government is very important for the athletic clubs. The comparison between the achievement of 
medals and the needs of fund for Athletics is different than other sports. Therefore, Athletics should be given higher priority. In this regard, the data from the five athletic clubs within the study show that the support from the government has been low in terms of coaching activities. The reason is that the coaching programs of the athletic clubs have been oriented toward the national and the international level.

The Law Number 3 or 2005 on the National Sports System in Article 23 verse 2 states that the development of the sports should be pursued by the sports club in the nearby society. The sports coaching activities should involve the active participation from the nearby society in the form of concerns toward specific sports branch such as Athletics. With regards to the support from the government and the society, the data from the five athletic clubs within the study show that the support has been in the "Moderate" level. The reason is that only several people within the nearby society support the training programs and the coaching activities.

According to (Lutan, 2013, p. 37), the management of the sports events should be based on the principles of Economics in order to attain satisfying added value or revenue. One of the income sources for the sports events is sponsorship. Sponsor, or sponsorship, is one of the solutions for attaining additional funds or for covering the other needs of the athletic clubs. In this regard, the data from the five athletic clubs within the study show that the achievement of the sponsorship has been in the "Low" level. The reason is that the branches in Athletics do not involve many people and thus these branches become less interesting.

The Supports from the Parents

Permission given by the parents of the athletes is highly important because the permission might be a motivation for the athletes and thus the coach will not be hesitant in designing the training programs for the athletes. In this regard, the data from the five athletic clubs within the study show that the supports from the parents have been in the "Good" level. The parents of all athletes in the five athletic clubs within the study have completely permitted their children to join the training programs in these athletic clubs.

Motivation or encouragement from the parents to the athletes is heavily necessary because there is not any guarantee that the athletes will always be in good conditions all the time. Since parents are the closest individuals to these athletes emotionally, it is very important for the parents to motivate the athletes as their children. Through motivation, athletes will be able to improve their capacity. In this regard, the data from the five athletic clubs within the study show that the motivation provided by the parents to the athletes has been in the "Good" level.

The communication between the coaches and the parents is ultimately necessary so that the athletes might be appropriately guided in both the training ground and the house. The feedback from the parents with regards to the complaints of the athletes will be very helpful for the coaches in understanding the athletes. With regards to the complaints of the athletes, the communication between the coach and the parents in the four athletic clubs within the study has been in the "Good" level while in one athletic club has been in the "Moderate" level. In the four athletic clubs within the study, there has not been any complaint from the athletes to the parents in relation to both the training process and the sports coaching activities. On the other hand, in one of the five athletic clubs within the study, namely the Sportif Athletic Club, the athletes have been complaining about the transportation facility but these complaints are still reasonable due to the difficult geographic situations. In other words, the geographic situations have posed some kind of difficulties during the training period.

The relationship among the parents, the coaches and the caretakers (management) is ultimately necessary in supporting the coaching process and in maintaining the continuity of the coaching process within the athletic clubs. In addition, the relationship among the parents, the coaches and the caretakers has been in the "Good" level. This relationship takes the form of good communication among the parents, the coaches and the caretakers. For example, in the Sportif Athletic Club there has been regular meeting that serve as a kinship forum for sharing the opinions around the coaching activities.

\section{Support from the Science}

Every coach and parent should apply good assessment; in this regard, the scientific observation technique might be implemented. Several coaches and clubs have access (including financial facilities) 
to the laboratory that might administer the physiological test, the psychological test and the biomechanical test for evaluating the athlete improvement, the athlete performance, the athlete performance, the technical efficiency and the mental power (Bompa, 2000, p. 177). According to (Gomez-Cabrera et al., 2006, p. 31), sports lead to the increasing plasma xanthine activities within the oxidation process and the increasing activity of $\mathrm{Nf}-\mathrm{Kb}$ in the peripheral blood lymphocytes after performing the marathon running. This activation depends on the formation of the free radicals. The Reactive Oxygen Species (ROS) that has been resulted from the training activities serve as the signal that regulates the important molecular process within the cellular adaptation for the training process among the athletes. Thereby, the free radicals serve as a double-edged sword. The free radicals have caused the oxidative damage but in the same time the free radicals have also regulated the expression of the enzymes that are important for the anti-oxidant defense. Consequently, the use of anti-oxidant supplement prior to the training activities should be prohibited because the use of the anti-oxidant supplement might prevent the adaptation within the training process. The results of the study by Cabrera show that adaptation has been one of the physiological factors might influence the training factors (Gomez-Cabrera et al., 2006). Thus, it might be inferred that the support from the science has very important for the coaching activities of the running athletes because through the support from the science the achievement of the athletes might be more under-controlled and the athletes might be avoided from the training risks as early as possible. With the support from the science, the training results might be improved more immediately and certainly the athletic clubs are always kept in update with the development of the science that has been implemented in the domain of sports throughout the other countries. Departing from this elaboration, the availability of both health experts and nutrition experts as the competent persons, as well as the availability of the facilities in the domain of physiological test has been ultimately important.

As having been implied, the availability of the health experts and the nutrition experts within the coaching process is ultimately important. The data from the five athletic clubs within the study show that the availability of the health experts and the nutrition experts has been one of the physiological factors that might influence the training results. Thereby, it might be concluded that the support from the science has been ultimately important for the coaching activities of the running athletes. The presence of the support from the science will make the achievement of the running athletes be more manageable and in the same time will also decrease the potential risks that the athletes might suffer from due to the training process especially if the potential risk have been identified as early as possible. Despite the fact that the availability of both the health experts and the nutrition experts has been ultimately important for the coaching process, the data from the five athletic clubs within the study show that the availability of both the health experts and the nutrition experts has been in the "Low" category. The reason is that these athletic clubs have not provide any regular examination by the health experts and the nutrition experts for the sake of coaching the athletes.

The function of sports science and technology is to find innovation in the coaching process. The implementation of the sports science and technology is necessary for delivering information so that appropriate decisions might be made in the training process (Lutan, 2013, p. 47). Then, in order to monitor the athletes development, the biomotor test should be administered within the coaching process. In this regard, the data from the five athletic clubs within the study show that the test instrument and the test administration of two athletic clubs have been in the "Moderate" category whereas the test instrument and the test administration of the remaining three athletic clubs, namely the Sportif Athletic Club, the Sembada Athletic Club and the BNHK Camp Athletic Club have been in the "Low" category. The "Low" category has been caused by the fact that the biomotor test has not been administered during the training process in the athletic club but, instead, the biomotor test has been administered only in the training camp. Furthermore, the results of the data analysis toward the five athletic clubs within the study in this regard explain that the administration of the biomotor test in each athletic club has not involved the relevant departments. Unlike this finding, the relevant departments have been involved in the test administration for the athletes who have joined the training camp such as: a) the centres of training and education for the young athletes; b) the centre of regional training; and c) the events under the scope of the National Committee of Sports.

\section{Input}




\section{Psychology, Evaluation, and Technology in Educational Research, 1 (2), 2019, 111}

Eki Aldapit, Suharjana Suharjana

The Input Evaluation in the study consists of the following part: (a) the quality of the facility availability; (b) the athlete availability/the athlete selection; and (c) the athlete competence. Each aspect will be explained further as follows.

The Quality of the Facility Availability

The indicator for the achievement of the coaching programs in this regard is the fulfillment of the standardized sports facility. The frequency on the use of the sports facility should be adjusted to the national-scale events. For example, with regards to the athletic stadium the high priority should be set on the running tracks and the jump box (Lutan, 2013). Then, the data from the five athletic clubs show that the achievement for the quality of the facility availability has been in the "Low" category. Actually, the facilities in the athletic clubs have been sufficient but these facilities are still insufficient for meeting the objectives of the events targeted by the five athletic clubs. The expected facilities are namely tartan athletic tracks instead of gravel athletic tracks that have been used in the training process.

\section{The Athlete Availability / The Athlete Selection}

Talent scouting has been the most strategic pillar for maintaining the athlete cycle. The talent scouting is conducted since the early age and is associated to the readiness and the maturity from both the physical and the psychological perspective under the efforts of pursuing achievements (Lutan, 2013 , p. 41). The athlete availability and the athlete selection have been in the "Good" category in four athletic clubs and have also been in the "Moderate" category in one athletic club. The achievement of the "Good" category among the four athletic clubs has been due to the fact that the four athletic clubs are scouting the athletes from the sports events that have been held by the Office of Education such as Youth Regional Sports Championship and the Youth National Sports Championship.

\section{The Athlete Competence}

The coaches and also the assistant trainers are the most compulsory element for improving the achievement. The recruitment of the coaches thus has been a crucial issue from the aspect of quantity and quality (Lutan, 2013, p. 45). The main responsibility of the leader is to manage the human resources among the followers in the efforts of dealing with the national obstacles. An effective leader is the one that might meet the needs of his or her followers and might also meet his or her own need. In order to meet this objective, there should be professional coaches and individuals who are able to support the performance of the coaches. In performing the duties, a coach should have the competence and the responsibility in coaching and developing the talents, the skills and the knowledge of the athletes under his or her coaching activities. The professionalism of the coach in performing the coaching activities has been "Good" in all of the five athletic clubs. Each of the athletic clubs has the coach and the assistant coach.

The quality of a coach is reflected from his or her advanced knowledge and increasing expertise; the two aspects always become the benchmark for the possibilities of pursuing the achievement. The knowledge itself is associated to the philosophy of the coaching objective and this includes ethics (Lutan, 2013, pp. 45-46). The level of education is considered important because it will help the coach in understanding the problems that take place within the coaching activities. The level of education for a coach who has been graduated from the Department of Sports is not always be the benchmark of success for an athletic club. In this regard, the data that have been attained from the four athletic clubs within the study show that the background of the coach is not related to the Department of Sports. Furthermore, the data from the five athletic clubs within the study show that the quality of the coach has been in the "Moderate" category. This category is apparent from the level of education that the coach has: the coach is not from the graduates of the Department of Sports.

The training programs that have been designed by the coach refer to the strategies for pursuing the achievements of the athletes as optimum as possible. The training programs thus are designed in accordance to the degree of the objective namely the long-term objective and the middle-term objective. Planning the training programs is an important competence that a coach should master. The role of a coach in preparing the athletes to deal with the competitions is a very vital aspect. The coach should plan how to improve or to develop the technical skills, the physical skills, the tactics and also the mental or the psychological conditions of the athletes. Both the coach and the athletes will 
cooperate in executing both the long-term program and the short-term program. The long-term program might take place for 4 to 8 years or to 12 years in accordance to the achievement on each level of the objective. On the other hand, the short-term program might take place for 1 year or within 1 year in accordance to the objectives that should be met. The training programs are designed in details by paying attention to the training principles and the training factors or variables in the form of training size / dose. The design of the training programs should be a necessity in the sports coaching programs. With regards to this matter, all of the five athletic clubs within the study has achieved the "Good" category. All of the five athletic clubs have designed and implemented the training programs.

In addition, the background of the coach will assist the coaching process of the athletes. The background of the coach might be turned into a motivation for the athletes within the athletic clubs. The coach who used to be an athlete certainly masters the techniques and the strategies in the field better in comparison to the coach who just has the theoretical background. Therefore, the experience of a coach becomes important for the coaching process within any athletic club. In some cases, it is experience that encourages an athlete to work as a coach. Then, in this regard, the background of the coach in all of the five athletic clubs has been in the "Good" category. The implication of this category is that the coach of each athletic club in the study has used to be an athlete. This kind of background will certainly assist the coach to modify the training programs in accordance to the needs in the field. The background of an athlete for a coach will motivate the athletes so that the programs that have been given might be well-implemented. In order to improve the quality of the coaching activities, the objective in the programs for meeting the coach qualification is to afford the nationally-qualified coach with as many indicators of national qualifications as possible (Lutan, 2013, p. 93). The coaching license from the IAAF thus becomes ultimately important. The presence of the coaching license emphasizes that the coach is completely competent in the domains of Athletics. In this regard, the data from the five athletic clubs within the study show the "Good" category. The coach from each athletic club has already had the relevant coaching license. Even the coach from the BNHK Camp Athletic Club has the international coaching license.

\section{Process}

According to (Lutan, 2013, p. 95), the objective of the coaching programs is to implement the gradual coaching programs namely: a) the monthly training agenda; b) the annual cycle agenda; and c) the monthly training agenda. The control toward the program implementation is in the form of training programs as part of the coaching activities. In this regard, the data from the five athletic clubs within the study show the "Good" category. All of the five athletic clubs have the training programs as the guidelines for the conduct of the coaching activities. With these guidelines, the coaching process might be regularly implemented and the coach might measure the improvement on the capacity of the athlete.

One of the objectives in the coaching activities is to improve the game intensity (Lutan, 2013, p. 94). The level of a championship might expose different loads. In addition to the loads in a championship, the situations within a championship might also influence the athletes. Therefore, the athletes should have special preparation for competing in the given championship. The implementation of the special programs is already found in the training programs as the preparation for the athletes to gain the ultimate achievement. Then, in this regard, the data from the five clubs within the study achieve the "Good" category. The reason is that the five athletic clubs have special programs for preparing the athletes as they get closer to the event. However, the special preparation within the five athletic clubs has suffered from several obstacles and one of these obstacles is mainly related to the problems of nutrition sufficiency. The coach will not have enough courage to provide special preparation in the form of training programs without sufficient nutrition intake. Any coach is aware of the danger that might appear to the surface if the athletes are pushed into the special preparation without the sufficient nutrition intake. The nutrition intake sufficiency might not be met due to the limited fund in the coaching process of each athletic club.

The danger that lies within the nutrition insufficiency might be understood. According to the results of a study by (Chen et al., 2008, pp. 1261-1268), consuming the amount of the most important carbohydrate might influence the factor of pre-training food consumption in modifying the response of immunoendocrine for the long training process. The huge effect of the evaluation process for improving the effectiveness of coaching activities is that when the coach starts to implement numerous 
strategies of assessment and evaluation he or she will identify the success or the failure of the training programs (Bell, 2006, p. 10). Therefore, evaluation on the training process should be conducted in order to control the improvement on the athletes' capacity. In relation to the statement, the data from the Bantul Athletic Club, the Sparta Athletic Club, the Sportif Athletic Club and the Sembada Athletic Club show that the implementation of the evaluation in the training program has been well-conducted. The evaluation toward the training results is implemented once in a month.

Furthermore, one of the objectives in the sports coaching activities is to implement the intensive coaching process through the amount of active hour (Lutan, 2013, p. 95). Both of the training frequency and the training intensity in the training programs are highly decisive for the achievement of the athletes. In this regard, the data from the four athletic clubs within the study, namely the Bantul Athletic Club, the Sparta Athletic Club, the Sportif Athletic Club and the BNHK Camp Athletic Club, show the achievement of the "Good" category. The four athletic clubs have trained for six days in each week and the training sessions are divided into several sessions but the number of the session is different from one athletic club to another.

Sports science is closely related to the educational theory. Two kinds of knowledge that has been independently developed by a coach or that has been developed in the community of coaches are the wisdom that has been commonly practiced and the knowledge related to the art of implementing the practical insight in the training situations (Lutan, 2013, p. 45). Science and technology have rapidly advanced and, therefore, a coach should identify the development of the athletes in every period in order to assist the development of the coaching activities. In order to support the good design of training programs, coach license should be held. Consequently, a coach should attend as many workshops and seminars as possible with regards to Athletics or the science that supports Athletics. The objective of attending as many workshops and seminars as possible is to gain novel knowledge on the development of the athletes and also the supporting insight. In this regard, the data from the five clubs within the study show the achievement of the "Good" category. Departing from these data, the coach of each athletic club is advised to attend the seminars and the workshops on the domains of Athletics so that he or she might expand their coaching capacity.

The concept of an organization is to serve as a coordinated unit that consists of at least two persons who serve to achieve certain goals (objectives) or a set of certain goals (objectives). In order to achieve this objective, there should be a coordination between the caretakers and the government, which has been an inseparable entity from the sports coaching activities. In the training process, the coordination between the relevant parties and both the athletes and the athletic clubs is highly important. In this regard, the data from all of the five athletic clubs within the study show that only three out of five athletic clubs show the achievement of the "Good" category. The three athletic clubs and the government have established good coordination and this coordination also includes the problems of finance. The government and the three athletic clubs always confirm the budget-related problems and provide aids to the three athletic clubs in the form of facilities although the aids have not been maximum yet. On the other hand, two out of five athletic clubs within the study show the achievement of the "Moderate" category. The government and the two athletic clubs only establish coordination nearby the events that will be attended; consequently, the coordination is only intended for the event.

\section{Product/Output}

The motive of achievement refers to the motive of keeping in pace with the prominence on the personal measures, the others' measures and the perfection in performing certain tasks. In relation to the statement, attaining as many medals as possible in the local-level competition is a kind of achievement that should be pursued. In this regard, the data from the Bantul Athletic Club, the Sportif Athletic Club, the Sparta Athletic Club, the Sembada Athletic Club and also the BNHK Camp Athletic Club have shown the achievement of the "Good" category. The five athletic clubs have achievement from the national level to the international level. In fact, one of the five athletic clubs within the study, namely the Sportif Athletic Club, has young athletes who have gained achievement in the international level. In relation to the context, the input and the process, the product / the output is influenced by the input and the process. The achievement from the five athletic clubs might exceed the national level if several factors might be supported. One of the factors that should be supported is the sufficient facilities and the sufficient fund. 


\section{Psychology, Evaluation, and Technology in Educational Research, 1 (2), 2019, 114}

Eki Aldapit, Suharjana Suharjana

\section{CONCLUSIONS}

Based on the data description, the data analysis and the discussion, several conclusions might be drawn in relation to the Context, Input, Process and Product Evaluation toward the five athletic clubs that have been based in the Province of Yogyakarta Special Region. These conclusions might be elaborated further in the following paragraphs.

First of all, the results of the Context Evaluation show that there have still been drawbacks within the implementation of the coaching programs for all number of running contest. The drawbacks are related to the provision of the budget, the availability of sufficient, the support from the government, the availability of both the health experts and the nutrition experts, the availability of both the test instrument and the bio-motor test instrument and also the site of the test and measurement administration.

Then, the results of the Input Evaluation show that there have still been drawbacks within the implementation of the coaching program for all numbers of running contest. The drawbacks are related to the main supporting facilities. In this regard, the intended main supporting facilities refer to the running track.

Next, the results of the Process Evaluation show that the coaching process has been implemented well although there have been drawbacks with regards to the equipment and the fund. The capacity of the coach in implementing the training process is very helpful for the pursuance of the achievement within the training programs. In relation to the statement, the athlete recruitment should be made open for all people so that the impressions of displaying nepotism and collusion might be avoided.

Last but not the least, the results of the Product Evaluation show that the achievement of the athletes have reached the national level and even the international level. However, such achievement will be better and be more continuous if the athletes are supported by the fine context and input in addition to the already fine process.

Thus, based on the results of the CIPP Evaluation, in general it might be concluded that the implementation of the sports coaching programs in the athletic clubs that have been based in the Province of Yogyakarta Special Region has been good but there are several aspects that should be given certain attention. The implication of the statement is that evaluation on the implementation of the coaching programs should be pursued by the athletic clubs. Through the administration of the CIPP Evaluation Model, it is expected that the implementation of the coaching programs among the athletic clubs based in the Province of Yogyakarta Special Region might be improved with regards to the long-term and continuous coaching prospect. In addition, the coaching activities should involve all sports components (stakeholders) so that the well-qualified athletes might be generated. In turn, these well-qualified athletes might gain achievement in multiple championships in the national and even in the international scale.

Indeed, the results of the coaching activities by the athletic clubs based in the Province of Yogyakarta Special Region have been good. However, the results of the analysis from the components of the CIPP Evaluation Model imply the limited facilities, fund and support. Therefore, it is suggested that the Caretakers of the Indonesian Athletics Federation in the Regional Level, the Caretakers of the Indonesian Athletics Federation in the Provincial Level, the Caretakers of the Indonesian Athletics Federation in the Central Level, the Caretakers of the National Sports Committee of Indonesia in the Regional Level and also the Caretakers of the National Sports Committee of Indonesia in the Central Level should assist the coaching process and the development of the athletes. The potentials of both the athletes and the coaches have been good and, therefore, it is possible that the athletes who have been coached in these athletic clubs might gain achievement even in the international level through proper priority and management.

\section{REFERENCES}

Arikunto, S. (2014). Metode penelitian kuantitatif, kualitatif, dan kombinasi (mixed methods). Bandung: Alfabeta.

Arikunto, S., \& Jabar, C. S. A. (2009). Evaluasi program pendidikan (2nd ed.). Jakarta: Bumi Aksara.

Astuti, D. A., Haryanto, S., \& Prihatni, Y. (2018). Evaluasi implementasi kurikulum 2013. Wiyata 


\section{Psychology, Evaluation, and Technology in Educational Research, 1 (2), 2019, 115}

Eki Aldapit, Suharjana Suharjana

Dharma: Jurnal Penelitian Dan Evaluasi Pendidikan, 6(1), 7-14. https://doi.org/10.30738/WIYATA DHARMA.V6I1.3353

Bell, K. (2006). A message from the coaches council: Using evaluation strategies to enhance coaching effectiveness. Strategies, 19(6), 7-10. https://doi.org/10.1080/08924562.2006.10591218

Bompa, T. O. (2000). Total training for young champions. Champaign: Human Kinetics.

Brown, L., \& Ferrigno, V. (2014). Training for speed, agility, and quickness, 3E. Human Kinetics.

Bukit, A. V, Bastari, A., \& Putra, G. E. (2019). Evaluation of learning programs in Indonesian Naval Technology College with the context, input, process, and product (CIPP) model. International Journal of Applied Engineering Research, 14(20), 3823-3827.

Chen, Y., Wong, S. H., Wong, C., Lam, C.-W., Huang, Y., \& Siu, P. M. (2008). The effect of a preexercise carbohydrate meal on immune responses to an endurance performance run. British Journal of Nutrition, 100(6), 1260-1268. https://doi.org/10.1017/S0007114508975619

Cresswell, J. (2016). Research design: Pendekatan metode kualitatif, kuantitatif, dan campuran (Edisi 4). Yogyakarta: Pustaka Pelajar.

Darmayanti, S. E., \& Wibowo, U. B. (2014). Evaluasi program pendidikan karakter di sekolah dasar Kabupaten Kulon Progo. Jurnal Prima Edukasia, 2(2), 223-234. https://doi.org/10.21831/jpe.v2i2.2721

Emzir, E. (2012). Metodologi penelitian kualitatif: Analisis data. Jakarta: Raja Grafindo.

Gomez-Cabrera, M.-C., Martínez, A., Santangelo, G., Pallardó, F. V., Sastre, J., \& Viña, J. (2006). Oxidative stress in marathon runners: interest of antioxidant supplementation. British Journal of Nutrition, 96(S1), S31-S33. https://doi.org/10.1079/BJN20061696

Hanifah, M., \& Irambona, A. (2019). Authentic assessment: Evaluation and its application in science learning. Psychology, Evaluation, and Technology in Educational Research, 1(2). https://doi.org/10.33292/petier.v1i2.4

Harsuki, H. (2012). Pengantar manajemen olahraga. Jakarta: PT Raja Grafindo Persada.

Hidayatullah, F. (2016). Pembangunan olahraga bagian integral dari pembangunan bangsa. In Pidato Pengukuha Guru Besar. Surakarta: Universitas Sebelas Maret.

Lutan, R. (2013). Pedoman perencanaan pembinaan olahraga. Bandung: Asdep Iptekor Kemenpora.

Mawardi, I. (2019). Evaluasi penerapan pembelajaran sistem blok di jurusan teknik pemesinan SMK Muhammadiyah Prambanan. Jurnal Pendidikan Vokasional Teknik Mesin, 7(2), 127-134. Retrieved from http://journal.student.uny.ac.id/ojs/index.php/mesin/article/view/14948

Miles, M. B., Huberman, A. M., \& Saldaña, J. (2014). Qualitative data analysis: A methods sourcebook. Los Angeles: Sage.

Mulyatiningsih, E. (2011). Riset terapan bidang pendidikan dan teknik. Yogyakarta: UNY Press.

Nuruhidin, A., Putra, F., Pamungkas, O. I., Ardiyanto, H., \& Saputro, D. P. (2018). An evaluation of powerlifting and weightlifting development program. Psychology, Evaluation, and Technology in Educational Research, 1(1), 1-8. https://doi.org/10.33292/petier.v1i1.19

Puspitasari, L., In'am, A., \& Syaifuddin, M. (2018). Analysis of students' creative thinking in solving arithmetic problems. International Electronic Journal of Mathematics Education, 14(1), 49-60. https://doi.org/10.12973/iejme/3962

Republik Indonesia. Undang-Undang Nomor 3 tahun 2005 tentang sistem keolahragaan nasional. , Pub. L. No. 3, Undang-Undang (2005).

Rohyani, R., Herpratiwi, H., \& Djasmi, S. (2014). Evaluasi program pembelajaran tematik. Jurnal Teknologi Informasi Komunikasi Pendidikan (Old), 2(4). Retrieved from http://jurnal.fkip.unila.ac.id/index.php/JT/article/view/5676

Stufflebeam, D. L. (2003). The CIPP model for evaluation. In International Handbook of Educational Evaluation (pp. 31-62). https://doi.org/10.1007/978-94-010-0309-4_4

Sudjana, D. (2006). Evaluasi program pendidikan luar sekolah untuk pendidikan nonformal dan pengembangan sumber daya manusia. https://doi.org/2006 
Psychology, Evaluation, and Technology in Educational Research, 1 (2), 2019, 116

Eki Aldapit, Suharjana Suharjana

Thumm, H. P. (2006). Talent identification in Indonesia: a model for other countries? New Studies in Athletics, 21(2), 29.

Thumm, H. P. (2019). Significance of basic training. Modern Athlete and Coach, 1, 9-12.

Tseng, K.-H., Diez, C. R., Lou, S.-J., Tsai, H.-L., \& Tsai, T.-S. (2010). Using the Context, Input, Process and Product model to assess an engineering curriculum. World Transactions on Engineering and Technology Education, 8(3), 256-261. 